\title{
Development of Biodegradable Seedling Pot using Konjac By-product of Industrial Waste
}

\author{
WAKako Lina ${ }^{\mathrm{a},}{ }^{*}$, Matsuoka Toshio ${ }^{\mathrm{b}}$, Matsumoto Yo-ichi $^{\mathrm{c}}$, \\ AzUMA Yoshiaki ${ }^{\mathrm{d}}$, TAKEUCHI Yasuharu ${ }^{\mathrm{d}}$ \\ a Institute of Science and Engineering, Kanazawa University, Kakuma-machi, Kanazawa, Ishikawa 920-1192, Japan \\ ${ }^{\mathrm{b}}$ Mie Prefecture Industrial Research Institute, Yokkaichi branch, 1-30 Shiohama, Yokkaichi, Mie 510-0851, Japan \\ ${ }^{\mathrm{c}}$ Faculty of Textile Science and Technology, Shinshu University, 3-15-1 Tokida, Ueda, Nagano 386-8567, Japan \\ d OHKAWA Co., LTD., 1-1 Tochimoto Shimoichi-cho, Yoshino, Nara 638-0031, Japan
}

Received 10 May 2013; accepted for publication 28 May 2013

\begin{abstract}
In recent years, global warming, the depletion of petroleum resources, and the reduction of carbon dioxide emission have become significant worldwide. Environmental considerations have been indispensable to the development and manufacturing industries. Considering this background, we aim to develop new and environmentfriendly agricultural materials using Konjac by-products of industrial waste.

Konjac by-products are a natural raw material sourced from the plants of the Amorphophalus family and are nutritious. Availing these advantages, we investigated the development of a novel biodegradable seedling pot manufactured from Konjac by-products, "Tobiko" in Japanese. The results are as follows: (1) The Tobiko seedling pot is able to be simply produced by molding of Tobiko gel which is composed of Tobiko powder and water; (2) The Tobiko seedling pots can maintain stable soil condition concerning sunlight and moisture, because the pot has a water absorbency of an amount almost equal to its own weight, and a light-resistance of 20 days; (3) The Tobiko seedling pot is biodegraded in only 27 days; therefore, the pots have excellent biodegradability compared with conventional biodegradable seedling pots. Therefore, in terms of time base, it is expected that Tobiko will be effectively used in manufacturing biodegradable seedling pots. And we believe to be a new and unique application for Konjac by-products.
\end{abstract}

Key Words: Konjac glucomannan, Tobiko, Industrial waste, Seedling pot, Biodegradability

\author{
廃棄コンニャク・グルコマンナンを活用した \\ 生分解性種苗育成用ポットの開発

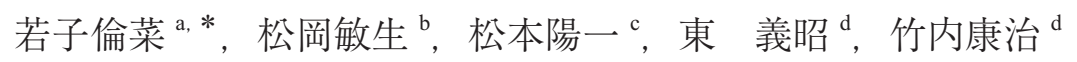 \\ ${ }^{a}$ 金沢大学理工研究域, ${ }^{b}$ 三重県工業研究所, ${ }^{c}$ 信州大学繊維学部, ${ }^{d}$ オーカワ(侏)
}

\section{1. 緒 言}

近年では，地球温暖化や化石燃料の枯渴危機などの背景か ら, 製品開発などのものづくりに扔いても地球環境への配慮 が極めて重要視されている。われわれは，廃棄コンニャク．
グルコマンナンを対象として，環境調和型繊維製品の開発を 検討している $[1,2]$.

コンニャク・グルコマンナン（Konjac Glucomannan，以下 KG と表す）は，サトイモ科の植物であるコンニャク芓から 精製される物質である。ささらに，粒子の大きさによって精粉 と飛粉（とびこ）に大別され，精粉を用いて製造されたゲル

\footnotetext{
* 連絡先 : 金沢大学理工研究域機械工学系 920-1192 金沢市角間町,

E-mail: linawakako@se.kanazawa-u.ac.jp, Tel: +81-76-234-4693, Fax: +81-76-234-4693
} 
状食品がコンニャクである。コンニャク食品は，その特有の 風合いと食感が古くから日本人の間で広く賞味されている伝 統食品のひとつであり, 現在はダイエット食品や健康食品と して大きく注目されている．精粉は大粒子であることからコ ンニャク食品の原料や工業的な表面処理剤などに用いられて いる，その $80 \%$ が食品用に，20\%が工業用に利用されてい る。一方で, 飛粉は非常に微小な粒子であるためにコンニャ ク製造には使用できず，また，デンプンや不純物などを多く 含み刺激臭をはなつために, 家畜の飼料としてわずかに利用 される以外はほとんどが産業廃棄物として処理されている. 廃棄 $\mathrm{KG}$ の廃棄量は毎年約 4,000～5,000tにものぼる [3].

しかしながら, KG が天然植物原料であることから, 廃棄 KG は環境調和型の農業用資材としての利用が大いに期待で きる $[4,5]$ ，すなわち，農業用資材の一つである種苗育成用 ポットとしての利活用を考える。種苗育成用ポットは, 作物 体の生育の初期に, 病害虫や不良環境などに対しての抵抗力 が弱いために, ビニールハウスなどの環境を管理できる設備 において利用される。種苗育成用ポットは，この期間におけ る作物体の管理や取扱い, 運搬などを容易にするための土壤 と種（あるいは苗など）の入れ物である。現在市販されてい る種苗育成用ポットにおいて主流となっているものは, 塩化 ビニルやポリエチレン等を原料として製造されたものである [6,7].これらの種苗育成用ポットは, 育成した苗を種苗育 成用ポットから取り出して本畑に定植する際に, 廃棄物とし て多量に処理されている。 また, 種苗育成用ポットから苗を 取り出す手間を必要とすること, さらにはこの作業によって 苗の根を傷める危険性があることが問題になっており [7], 改善が求められている.

また，廃棄 $\mathrm{KG}$ はコンニャク芋の皮などの不純物やデンプ ンを多く含んでいることから, 約 50\%が炭水化物, 約 $24 \%$ がタンパク質でそのうちの約 4\%が窒素であり, さらに約 8\%が灰分でカリウムやリンを豊富に含んでおり [8-10], 栄 養学的観点においても優れた特性をもつ。一般に, 窒素・リ ン酸・カリウムは, 植物の育成において特に重要な要素であ り，「肥料の三要素」といわれている。これらの三要素は, 作物が多量に吸収するために，土壤において不足しないよう に補給しなければならないものである。したがって, 廃棄 $\mathrm{KG}$ から作製された農業用資材が土壤中で生分解されれば, 作物の肥料としての寄与も期待できるであろう.

そこで本研究では, 産業廃棄物である廃棄 $\mathrm{KG}$ の有効利用 を目的として, 廃裹 KG（以下飛粉と表す）を用いた生分解 性種苗育成用ポットの開発について検討した。

\section{2. 実験材料と方法}

\section{1 実験材料}

原料には Fig. 1 に示す飛粉と水道水を用いた. 飛粉と水道 水との混合物は, 飛粉の濃度が増加すると液体状, ゲル状, 固体状へと変化することから, 成型に適したゲル状を形成で きる濃度でゲル状飛粉を作製した。すなわち， $50 \mathrm{ml}$ の水道

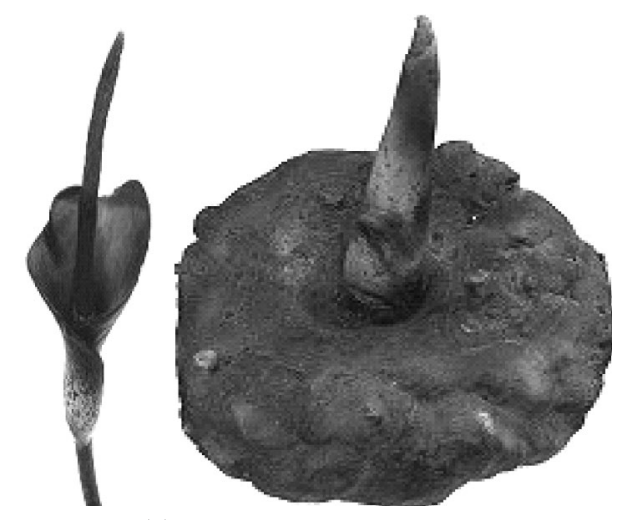

(a) Konjac potato and flower

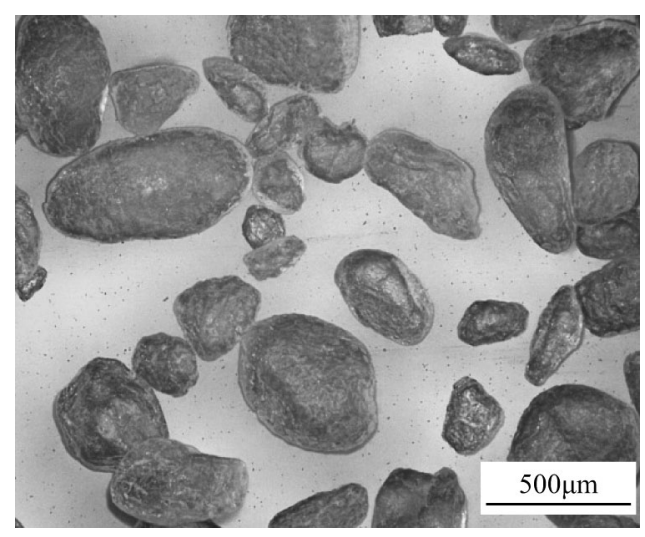

(b) Seiko

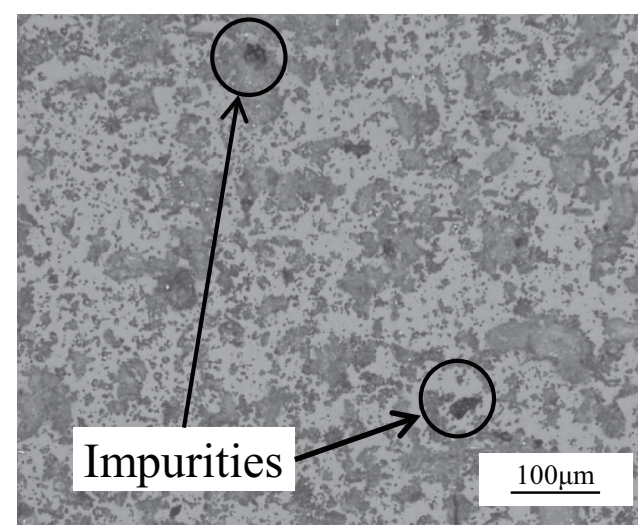

(c) Tobiko

Fig. 1 Photographs of konjac potato and glucomannan powder.

水に対して $35 \mathrm{wt} \%$ の飛粉を加えて, 自転公転式攪拌脱泡機 (THINKY 製 ARE-250) を用いて 40 分間の攪拌と回転数 2,200 rpm で 20 分間の脱泡を行った．攪汼・脱泡の条件は, 目視レベルで混合物が均一に混合され，気泡のない状態にな るまでとした。 ただし，攪拌操作によって混合物の温度が上 昇してしまうことから, 攪拌 20 分毎に冷凍庫内でゲル状飛 粉を 15 分間冷却した。調製したゲル状飛粉を用いて，飛粉 ポットと飛粉プレートを作製した.

飛粉ポットは, ゲル状飛粉を, 試作成型装置を用いてポッ ト形状に成型することによって作製した．Fig. 2(a)は試作成 型装置と飛粉ポットの成型方法を示す。テフロンシートで内 面を覆った雌型内に約 $75 \mathrm{ml}$ のゲル状飛粉を入れ, テフロン 


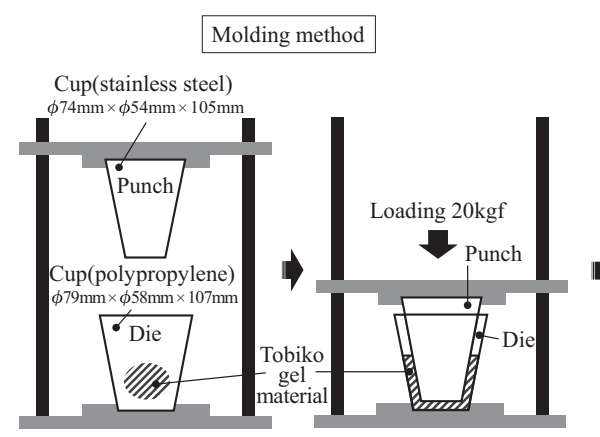

(a) Tobiko pot

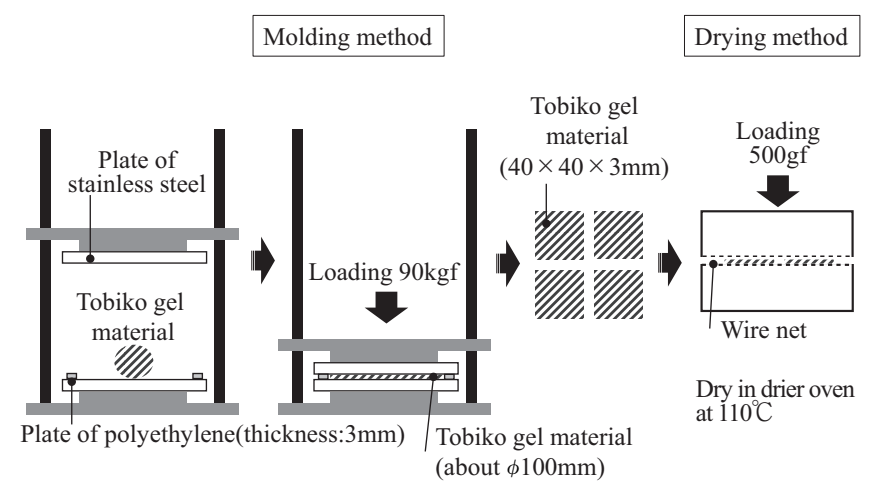

(b) Tobiko plate

Fig. 2 Brief method and process of molding.

シートで外面を覆った雄型を垂直にスライドさせた，試作成 型装置の上部から $20 \mathrm{kgf}$ の荷重を加えて試料の厚さが $3 \mathrm{~mm}$ になるまで加圧し, ポット形状に成型した。 その後, 試作成 型装置の上部の荷重を取り除き, さらに雌型と雄型ならびに テフロンシートを慎重に取り外して成型ポットを得た。カッ ターを用いてポットの高さが一定になるように整形して, 整 形ポットを作製した。続いて, 整形ポットはオーブン (YAMATO 製，DP-33）を用いて乾燥処理した。整形ポット は，外面をテフロンシートで覆った雄型を整形ポットの中心 と一致するように設置して, $300 \mathrm{gf}$ の荷重を負荷した状態で オーブン内のワイヤーネット上に設置した。 これを温度 $110^{\circ} \mathrm{C}$ で重量の変動がなくなるまでのおよそ3 日間留置して 乾燥させた。 その後オーブンから取り出し，雄型などを取り 除いて, 飛粉ポット試料を作製した。

飛粉プレートは, 飛粉ポットの作製方法と同様の方法で作 製した. Fig. 2(b)は試作成型装置と飛粉プレートの成型方法 を示す。試作成型装置を用いたシート形状の作製方法は次の と扔りである。すなわち，テフロンシートで表面を覆った 2 枚の板の間に約 $45 \mathrm{ml}$ のゲル状飛粉を入れ, 試作成型装置の 上部から $90 \mathrm{kgf}$ の荷重を加えて厚さ $3 \mathrm{~mm}$ のシート形状に成 型した。 その後, カッターを用いて $40 \mathrm{~mm} \times 40 \mathrm{~mm}$ の寸法 に注意深く切り離して, 整形プレートを作製した。ささらに, 整形プレートはオーブンを用いて乾燥処理した。整形プレー トは，2枚のワイヤーネットで挟み，さらにその上部から $500 \mathrm{gf}$ (ワイヤーネットの重量も含む) の荷重を負荷した状 態でオーブン内に設置した。これを温度 $110^{\circ} \mathrm{C}$ で 3 日間留置 して乾燥させて飛粉プレートを作製した。

\section{2 実験方法}

作物体の生長には, 安定した土壤と肥料の他に水分と日光 が欠かせない，種苗育成用ポットは，育苗期間に扔いて，水 やりや土壤中の水分, 日光にさらされながらもポット形状を 維持して土壤を安定した状態に保てることが最重要と考え る。また，種苗育成用ポットを用いた育苗では土壤の量が限 られるために水分が不足しやすくなることから，適度な水分 量の維持も重要になる。ささらに, 苗を種苗育成用ポットとと もに本畑に定植した後は, 苗の根の生長を妨げないために, 種苗育成用ポットは速やかに生分解される必要がある。 そこ で, 試作した飛粉ポットおよび飛粉プレートについて, これ らの種苗育成用ポットとして必要な性能と生分解性を調べ た。

なお，作物の種類によって播種から苗を本畑へ定植するま での育苗期間は異なる。同様に, 苗の根の生長速度も異なる ことから, 生長速度が速い種類の作物を参考にして, 播種か ら苗を本畑へ定植するまでの育苗期間を20日間，苗を本畑 へ定植した直後から完全に生分解されるまでの期間を 10 日 間とした。これらの期間を目標值として設定し, 各種性能を 調べた。

\subsection{1 吸水性試験}

Fig. 3 (a) は吸水性試験の概略図を表す. 水道水 $600 \mathrm{ml}$ が 入ったビーカー内に飛粉ポットを浸漬させて, 温度 $20 \pm$ $2^{\circ} \mathrm{C}$, 湿度 $65 \pm 5 \%$ R.H.の環境に留置した。 カビの增殖を防 ぐために，5日に 1 回，ビーカー内の水を慎重に交換した。 そして，播種から苗を定植するまでの育苗期間である20日 間が経過した後に, 飛粉ポットをビーカーから取り出し, 吸 水紙（日本製紙クレシア製 ティシュ100-S）を用いて飛粉 ポットの表面に付着した水分を取り除いて，その外観を観察 した。また，ノギス（Mitutoyo 製 530-101 N15）を用いて 飛粉ポットの上端における直径, 高さ，ならびに厚さを 4 か 所についてそれぞれに測定し, 平均值を求めた。 さらに, 飛 粉ポットの重量を, 電子天秤（Sartorius 製 TE124S）を用 いて測定した。繰り返しの実験回数は 10 回とし, 平均值を 求めた。 なお，吸水率 $W A R$ [\%]は次式(1)によって求めた。

$$
W A R=100 \times \frac{\left(A^{\prime}-A\right)}{A},
$$

ただし, $A$ は標準状態（温度 $20 \pm 2{ }^{\circ} \mathrm{C}$, 湿度 $65 \pm 5 \%$ R.H.) での重量 $[\mathrm{gf}], A^{\prime}$ は試験後の重量 $[\mathrm{gf}]$ である。

\subsection{2 耐光性試験}

Fig. 3(b)，（c）は耐光性試験機（スガ試験機製テーブルサ ン XT1-15）の内部と飛粉プレートの配置を表す. 試料に は飛粉プレートを 10 枚用いた。試験条件は， 1 年のうち日 照時間が最も長く全天日射量が最も多い 5 月を想定して, 放 射強度 $180 \mathrm{~W} / \mathrm{m}^{2}$ (波長範囲 300 700 nm)，播種から苗を本 


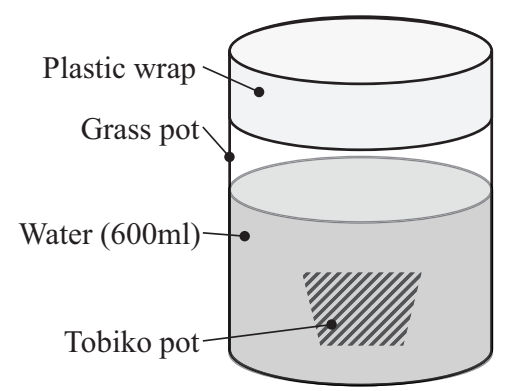

(a) Water absorbency testing

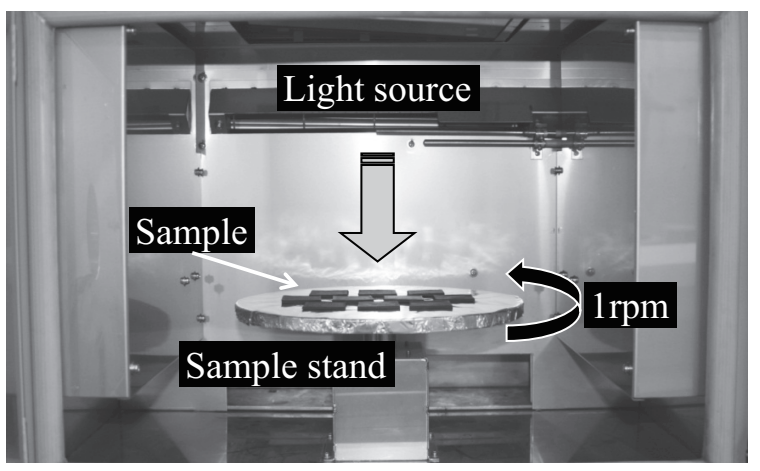

(b) Light-resistance testing

Tobiko plates (About $35 \times 35 \times 2 \mathrm{~mm}$ )

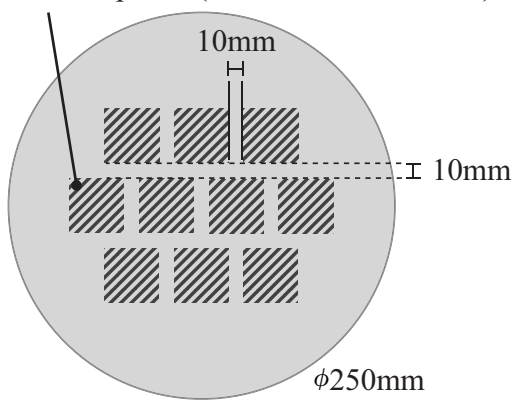

(c) Front view of sample stand in light-resistance testing instrument

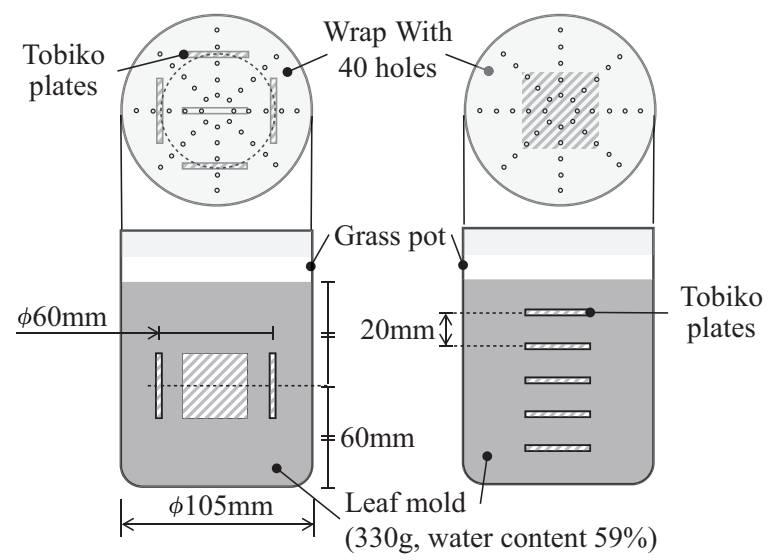

(d) Biodegradability testing

Fig. 3 Schematic illustration of various testings.
畑へ定植するまでの育苗期間である20日間に相当する放射 時間 131 時間とした。また, 試料台の回転速度は $1 \mathrm{rpm}$ と し, これらの試験は温度 $20 \pm 2^{\circ} \mathrm{C}$, 湿度 $65 \pm 5 \%$ R.H.の環 境室内にて実施した。

試験終了後には, 飛粉プレートの外観を観察し, 電子天科 （Sartorius 製 TE124S）を用いて重量を測定した。また，ノ ギスを用いて飛粉プレートの 4 辺の長さと, 角部 4 か所およ び中央部 1 か所の合計 5 か所の厚さを測定し，それぞれの平 均值を求めた。

\section{2 .3 生分解性試験}

Fig. 3(d) は生分解性試験の概要図を表す。試料には飛粉プ レートを 10 枚用いた。 ガラス製容器の中に腐葉土を入れ, 飛粉プレート 5 枚は鉛直方向に, 残りの 5 枚は水平方向に完 全に埋没するように設置した。そして, 夏場の土壤温度を想 定した温度 $35 \pm 22^{\circ} \mathrm{C}$, 湿度 $75 \pm 5 \%$ R.H.の恒温室 (エス ペック製 TBE-4HA6PX) 中に放置した。放置期間は5 日 間，10日間，15日間ならびに 20 日間の 4 条件とした。なお， 試験期間中には, 土壤の乾燥を防ぐために小型霧吹き器を用 いて 24 時間毎に $1 \mathrm{ml}$ の水道水を加えた。

試験終了後には, 土壤中から取り出した飛粉プレートの外 観を観察し，また，電子天秤を用いて重量を測定した。生分 解率 $B$ [\%] は次式(2)によって求め, 平均值にまとめた.

$$
B=100 \times \frac{\left(G-G^{\prime}\right)}{G},
$$

ただし， $G$ は試験前の絶乾重量 $[\mathrm{gf}], G^{\prime}$ は試験後の絶乾重 量 [gf] である.

\section{3. 結果と考察}

\section{1 吸水性試験}

Fig. 4 は吸水性試験の前後における飛粉ポットの外観を表 す。飛粉ポットの正面および側面を観察したところ, 亀裂や ひびなどは観察されなかった。また, Table 1 は吸水性試験 の前後における飛粉ポットの寸法および重量の測定結果を表 す。厚さや高さの寸法においても, やや増加したものの大き な変化はなく, ポット形状も維持できていた。 この結果か ら, 飛粉ポットは, 播種から苗を本畑へ定植するまでの育苗 期間である 20 日間において, 水やりや土壤に含まれる水分 などによる湿潤によって土壤が流出したり乾燥しやすくなる ことのない安定した土壌環境を維持できるものと考える. 加

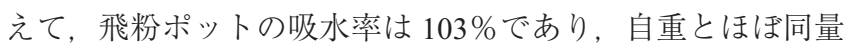
の水分を吸水するという高い吸水性を有していることもわ かった，飛粉ポットの保水性や土壤との間の水分移動特性に も影響を受けるが, この土㙵に接しているポットに多量に水 分を取り达める性能は, 少なくとも従来の塩化ビニルやポリ エチレン等を原料とする吸水性をもたない種苗育成用ポット と比較して, 土壤の適度な水分量の維持に有効であるものと 考えられる. 特に小型の種苗育成用ポットでは, 土壤が少量 


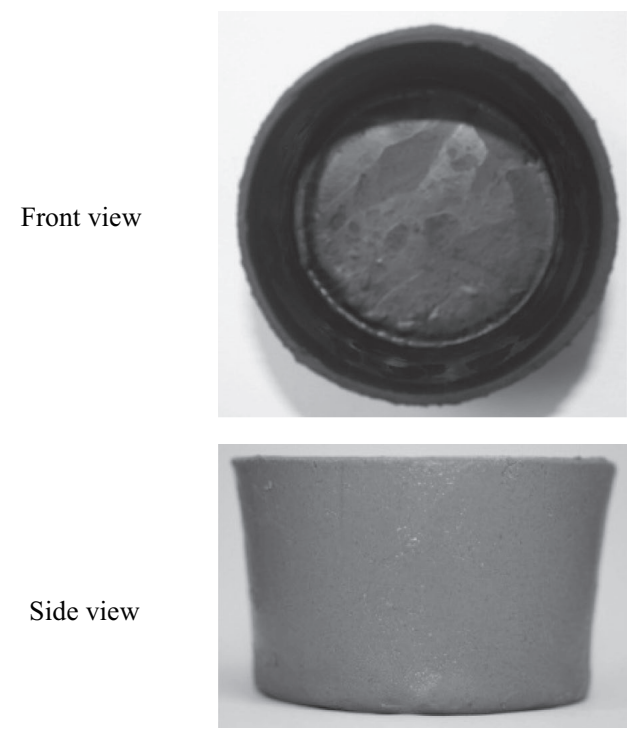

(a) Before
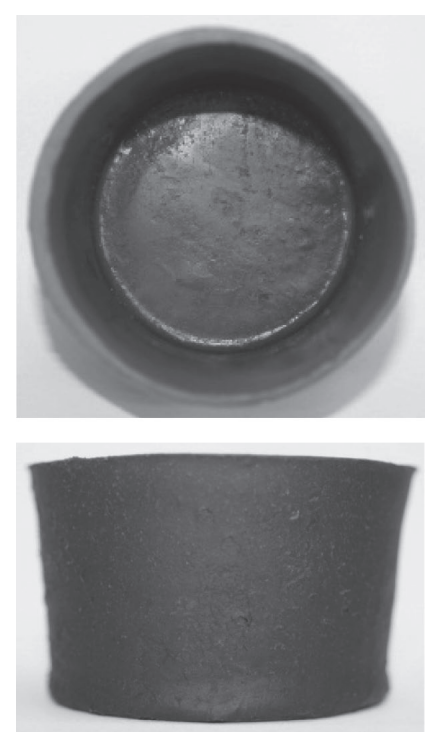

(b) After 20 days

Fig. 4 Tobiko seedling pots before and after water absorbency testing.

Table 1 Size and weight of Tobiko pot in water absorbency testing.

\begin{tabular}{lcc}
\hline & Before & After 20 days \\
\hline Thickness $[\mathrm{mm}]$ & 2 & 3 \\
$\mathrm{SD}$ & 1 & 1 \\
Diameter $[\mathrm{mm}]$ & 59 & 61 \\
$\mathrm{SD}$ & 1 & 1 \\
Height $[\mathrm{mm}]$ & 35 & 42 \\
$\mathrm{SD}$ & 1 & 1 \\
Weight $[\mathrm{g}]$ & 13.4 & 27.2 \\
\hline
\end{tabular}

SD: standard deviation

であるために水分量がより不足しやすくなるが，飛粉ポット を用いることによって, より効果的に適度な水分量を維持で きるものと考元られる，また，水分量を維持しやすくなれ ば, 水やりの手間の軽減効果も期待できる。 さらに，土壤中 の水分の過剩な状態が続くと苗の根が根腐りする危険性が生 じるが，飛粉ポットの吸水性は過剩な水分の調整にも効果的 と考えられる。

\section{2 耐光性試験}

Table 2 は耐光性試験の前後における飛粉プレートの寸法 の測定結果を表す。充苗期間である 20 日間に至る 5 日間, 10 日間および 15 日間の測定結果も併せて示した. 全ての期 間において亀裂やひびは観察されなかった。 また, 飛粉プ レートの辺の長さ, 厚さおよび重量は, 全ての期間において 試験の前後での大きな変化はなく, 有意水準 $\mathrm{p}>0.05$ で有 意な差は認められなかった. 飛粉プレートへの光照射量が最 大（すなわち, 飛粉プレート面が光入射方向に対して垂直）
Table 2 Size of Tobiko plate in light-resistance testing.

\begin{tabular}{llcccc}
\hline & 5 days & 10 days & 15 days & 20 days \\
\hline \multirow{4}{*}{ Before } & Length of side $[\mathrm{mm}]$ & 34.9 & 34.0 & 34.9 & 34.8 \\
& SD & 0.7 & 0.6 & 0.7 & 1.8 \\
& Thickness $[\mathrm{mm}]$ & 2.5 & 2.0 & 1.9 & 1.9 \\
& SD & 0.4 & 0.2 & 0.6 & 0.4 \\
\hline \multirow{3}{*}{ After } & Length of side $[\mathrm{mm}]$ & 34.9 & 34.0 & 34.9 & 34.8 \\
& SD & 0.6 & 0.6 & 0.7 & 1.8 \\
& Thickness $[\mathrm{mm}]$ & 2.6 & 2.0 & 2.0 & 1.9 \\
& SD & 0.4 & 0.2 & 0.5 & 0.4 \\
\hline & & \multicolumn{4}{c}{ SD: standard deviation }
\end{tabular}

になる試料設置条件下で，播種から苗を本畑へ定植するまで の育苗期間である 20 日間の光照射を受けてもプレートの形 状を維持できたことから，ポット形状の場合においても十分 な耐光性をもつものと推測される. したがって, 飛粉ポット は, 日光にさらされることによって土壤が乾燥させられたり 流出しやすくなることもなく, さらに, 崩壊部からの日光の 侵入によって苗の根の健全な生長が妨げられることのない安 定した土壌環境を維持できるものと考える.

\section{3 生分解性試験}

Fig. 5 および Table 3 は生分解性試験の前後における飛粉 プレートの外観と生分解率について表す．埋没後の日数が増 加するにつれて飛粉プレートの表面は変色し, 形状が崩れて いることもわかった。 また埋没後 20 日間では，プレートが 原型を維持できないほどに分解されていた，生分解率におい ては埋没後の日数の増加とともに増加していた. Fig. 6 にお 34.8 けるムマーカによるプロットは埋没後の日数と生分解率 

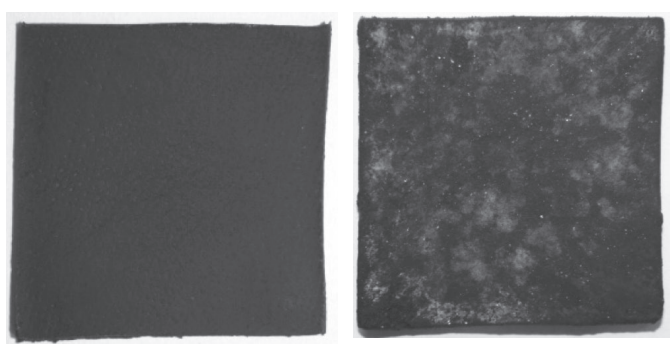

Before
After

5 days

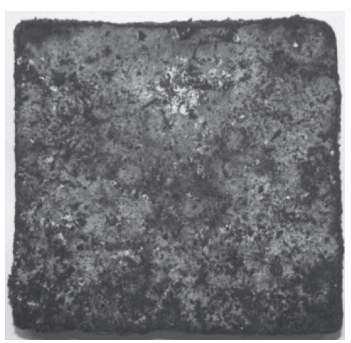

After

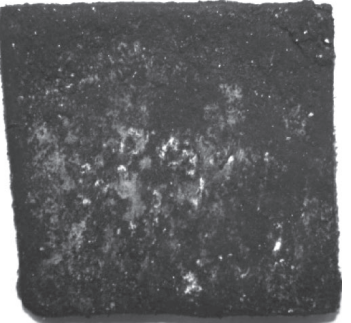

After

15 days

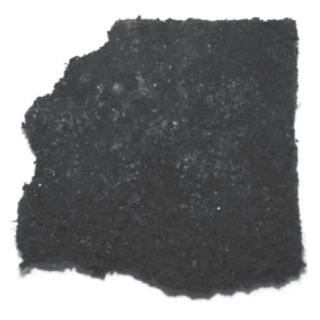

After

Fig. 5 Progress of biodegradation on Tobiko plate.

Table 3 Biodegradability of Tobiko plate.

\begin{tabular}{|c|c|c|c|c|c|}
\hline & \multirow[t]{2}{*}{ Before } & \multicolumn{4}{|c|}{ After } \\
\hline & & 5 day & 10 days & 15 days & 20 days \\
\hline Biodegradability [\%] & 0 & 20 & 38 & 47 & 68 \\
\hline
\end{tabular}

との関係を表す。飛粉プレートの生分解率は埋没後の日数と 直線関係にあった。そこで，最小二乗法を用いて近似直線を 求め, 生分解率が $100 \%$ に達するまでに必要な埋没日数を計 算したところ，約 30 日間であることが推測された。一方で, 飛粉ポットを用いて育苗している期間にも, 飛粉ポットは ポット内の土壤に生息する微生物によって生分解される。播 種から苗を本畑へ定植するまでの育苗期間である 20 日間に おける飛粉ポットの生分解率を計算によって推測した。すな わち, 埋没後 20 日間における生分解性試験の結果から, 腐 葉土の単位重量当たりの生分解量は約 $0.06 \mathrm{gf}$ であった。試 作した飛粉ポットを十分に満たすために必要な土壤の量は, 飛粉ポットの容量と実験で使用した腐葉土の密度から換算す ると約 $27 \mathrm{gf}$ であり, 飛粉ポットの埋没後 20 日間での生分 解量から生分解率を計算するとおよそ $10 \%$ あ゙あった。この 育苗期間中の生分解率を, 定植後 (埋没後) の日数と生分解 率との関係に加算した結果がFig. 6 におけるロマーカによる プロットである。この関係式から, 育苗期間を通して定植後

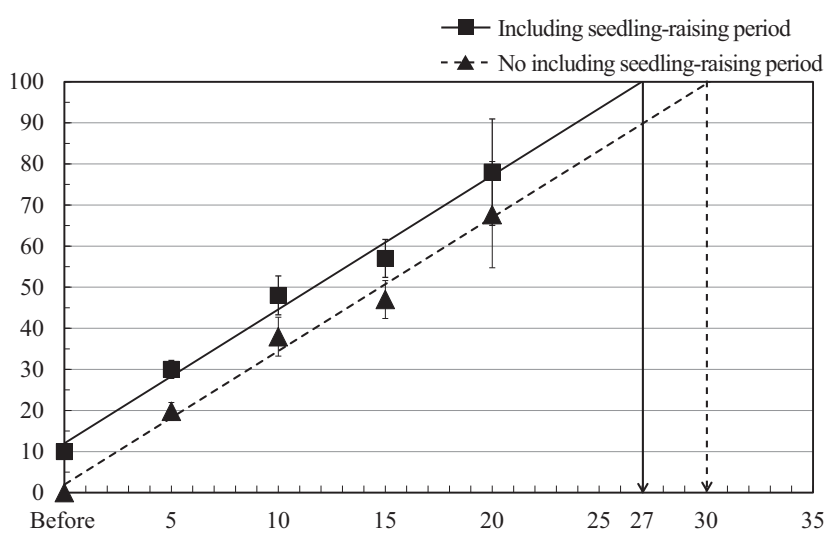

Fig. 6 Relationship between biodegradability and time from planting.
に生分解率が $100 \%$ に達するまでの期間を求めたところ, 約 27 日間であると推測される.

現在市販されている生分解性をもつ種苗育成用ポットに は, 竹, ココヤシ，羊毛，ポリ乳酸などを原料に作製された ものがある。これらの種苗育成用ポットにおいて生分解率が $100 \%$ に達するまでには数か月から数年が必要とされる。こ のような他製品との生分解性の比較では統一された実験条件 下での比較検討が重要であるが, ここでは単純に時間軸のみ で比較するものとすると, 飛粉ポットは生分解の速度が極め て早く，非常に優れた生分解性をもつことがわかった。した がって, 飛粉ポットは, 生長速度が速い種類の作物への利用 が十分に期待できる。

\section{5. 結 言}

産業廃棄物である廃棄 $\mathrm{KG}$ (飛粉) の有効利用を目指して, 飛粉を用いた生分解性の種苗育成用ポットの開発について検 討した。 その結果は次のと抢りである。(1) 飛粉ポットは, 飛粉を水でゲル化して加圧成型することによって簡単に作製 できる。（2）自重とおよそ等倍もの吸水性と20日間の耐光 性が認められ, 水分と日光に対しての安定した土壤環境を維 持できる。 (3) 約 27 日間の短い生分解期間が認められ, 時 間軸での比較において, 従来製品と比較して優れた生分解性 がある。したがって, 生分解性種苗育成用ポットとしての利 活用が十分に期待できる.

今後の課題：種苗育成用ポットの利用においては, 苗を本 畑へ定植した後は苗の根の生長を妨げないことも重要であ る。試作した飛粉ポットは, 苗を本畑へ定植した後に生分解 率が $100 \%$ に達するまでの所要日数が約 27 日間必要である ため, さらなる生分解速度の制御について検討する必要があ る。したがって, 飛粉ポットにおける飛粉量調整による生分 解速度の制御や試作飛粉ポットを用いた実際の種苗育成試験 を検証する必要がある。また, これらの性能について, 統一 された条件下での既製の生分解性種苗育成用ポットとの比 較・検証も必要と考える. 


\section{References}

[1] Honda T, Matsumoto Y, Wakako L, Azuma Y, Takeuchi Y (2011) J Text Eng, 57, 107-113

[2] Matsumoto Y, Okawa Co., Ltd (2007) Japanese Patent 3927061

[3] Okimasu S (1993) "Science of Konjac", pp244-245, Keisuisha

[4] Shimaji K, Sudo S, Harada H (1976) "Mokuzai no Sosiki”, p47, p49, Morikita Publishing

[5] Sakurai N, Yamamoto R, Kato Y (1991) "Syokubutsusaibouheki to Tatorui", pp33-37, 115-117,
170, Baifukan

[6] Maki H, Iwata H, Ooshio T (2002) Bull Hyogo Pre Agri Inst (Agriculture), 50, 29-32

[7] Nishi Y, Takemure M, Tabuo H, Yokoyama M (2012) Plant Prot, 66, 687-691

[8] Kihara Y, Tada S (1957) J Util Agric Prod, 4, 38-40

[9] Kimura T, Sasaki H, Kameda K, Sugahara T (2001) J Integr Stud Diet Habits, 12, 160-166

[10] Niwa T, Maekawa K, Etoh H, Shimizu A, Shimizu Y, Kato K (2001) Nippon Shokuhin Kagaku Kogaku Kaishi, 48, 943-947 